\title{
Effect of volume of participation in exercise programs on biochemical parameters of women
}

\author{
Efeito do volume de participação em programas de exercícios nos parâmetros \\ bioquímicos de mulheres
}

\section{AUTHOR'S \\ Karina de Almeida Brunheroti ${ }^{1,4}$ (D) \\ Alynne Christian Ribeiro Andaki ${ }^{2}$ (D) \\ Eduardo Kokubun ${ }^{3}$ (D) \\ Camila Bosquiero Papini ${ }^{2,4}$ (D) \\ 1 Universidade Federal do Triângulo Mineiro, Programa de Pós Graduação em Educação Física, Uberaba, Minas Gerais, Brasil. \\ 2 Universidade Federal do Triângulo Mineiro, Departamento de Ciências do Esporte, Uberaba, Minas Gerais, Brasil. \\ 3 Universidade Estadual Paulista, Departamento de Educação Física, Rio Claro, São Paulo, Brasil. \\ 4 Grupo de Estudos e Pesquisas em Atividade Física, Exercício e Saúde, Universidade Federal do Triângulo Mineiro, Uberaba, Minas Gerais, Brasil.}

\section{CORRESPONDING}

Karina de Almeida Brunheroti

karina_brunberoti@outlook.com

Rua Rio de Janeiro, n. 94B. Santa Maria,

Jaguariúna, Brasil.

CEP: 13911-264.

DOI

10.12820/rbafs.27e0239

\section{(cc) BY}

This work is licensed under a Creative Commons Attribution 4.0 International License.

\begin{abstract}
The aim of the study was to evaluate the effect of the volume of participation in exercise programs offered in Primary Health Care (PHC), for 24 weeks on blood biochemical parameters of adult women. Three Basic Health Units in Rio Claro City (São Paulo) were selected and 2 exercise interventions were implemented with different volumes ( 3 weekly sessions, 90 minutes each; 2 weekly sessions, 60 minutes each). In total, 53 participants remained until the end of the interventions. Regardless of their number of absences, they were divided into 4 groups, according to the volume of participation (calculated individually according to the duration of sessions and the number of classes held), forming groups according to quartiles: Low Volume Group (LVG; $57.62 \pm 9.97$ years-old), Low Medium Volume Group (LMVG; $56.31 \pm 12.18$ years-old), High Medium Volume Group (HMVG; $53.00 \pm 10.25$ years-old), and High-Volume Group (HVG; $59.69 \pm 7.66$ years-old). Blood biochemical parameters were dosed using the ELISA method. The Generalized Estimation Equation Model was used to compare the biochemical parameters (time, group, and interaction; $\mathrm{p} \leq 0.05$ ). The analysis showed significant and positive time effect for low-density lipoproteins (LDL) and glycemia in all groups and for total cholesterol (TC) in LVG, LMVG and HMVG; a significant group effect for HVG on TC (higher levels compared to all other groups) and LDL (higher levels compared to LVG and LMVG). It is concluded that the physical exercise programs offered in the PHC contributed to a significant reduction in LDL and blood glucose levels, regardless of the volume of participation of individuals in the programs.
\end{abstract}

Keywords: Physical activity; Primary health care; Risk factors; Community participation.

RESUMO

O objetivo do presente estudo foi avaliar o efeito do volume de participação em programas de exercícios, ofertados na Atenção Primária à Saúde (APS), durante 24 semanas, nos parâmetros bioquímicos sanguíneos de mulheres adultas. Foram selecionadas 03 Unidades Básicas de Saúde de Rio Claro-São Paulo implementadas 2 intervençôes de exercícios com diferentes volumes ( 3 sessöes/semana, 90 minutos cada; 2 sessöes/semana, 60 minutos cada). No total, 53 participantes se mantiveram até o final das intervençôes, independentemente do número de faltas foram divididos em 4 grupos, de acordo com o volume de participação (calculado conforme a duração das sessões e a quantidade de aulas realizadas de forma individual), formando os grupos segundo os quartis: Grupo Baixo Volume (GBV; 57,62 \pm 9,97 anos), Grupo Baixo Médio Volume (GBMV; 56,31 $\pm 12,18$ anos), Grupo Médio Alto Volume (GMAV; 53,00 $\pm 10,25$ anos) e Grupo Alto Volume (GAV; $59,69 \pm 7,66$ anos). Os parâmetros bioquímicos sanguineos foram dosados pelo método ELISA. Foi utilizado - Modelo de Equações de Estimaçôes Generalizadas para a comparação dos parâmetros bioquímicos (tempo, grupo e interação; $p \leq 0,05)$. A análise evidenciou efeito significativo favorável do tempo para lipoproteinas de baixa densidade (LDL) e glicemia em todos os grupos e para colesterol total (CT) no GVB, GBMV e $G M A V$; e efeito significativo do grupo para GAV no CT (maiores niveis comparado a todos os grupos) e $L D L$ (maiores niveis comparados ao GBV e GBMV). Conclui-se que o programa de exercício físico ofertado na APS contribuiu para a redução significativa dos niveis de LDL e glicemia, independentemente do volume de participação dos indivíduos nos programas.

Palavras-chave: Atividade física; Atenção básica à saúde; Fatores de risco; Participação da comunidade.

\section{Introduction}

Chronic non-communicable diseases (NCDs) are characterized by a set of pathologies with multiple causes and risk factors, representing a major public health problem ${ }^{1,2}$. Among these diseases are cardiovascular diseases and their associated factors, such as dyslipidemia, diabetes mellitus, and arterial hypertension ${ }^{3}$. According to the Pan American Health Organization $(\mathrm{PAHO})^{4}$, more people have died from cardiovascular diseases than from other causes and most of these di- 
seases can be prevented by adhering to the practice of physical exercise and regular physical activity $(\mathrm{PA})^{5}$.

Thus, there is an association between cardiovascular health and the regular practice of exercise and PA, which promotes numerous benefits and physiological adaptations linked to this system, such as improving body composition ${ }^{6,7}$, aerobic capacity, resting heart rate, and blood biochemical parameters ${ }^{5,8-13}$, such as low-density lipoprotein (LDL), high density lipoprotein (HDL), triglycerides (TG), total cholesterol (TC), blood glucose, and C-reactive protein (CRP). It is known that all these benefits are dependent on a dose-response relationship of physical exercise. Although currently the minimum recommendations for PA are 150 minutes/week, the World Health Organization (WHO) guideline ${ }^{14}$ warns countries to develop national health policies and leaves an important message for the population: "Every move counts", evidencing a possible quality of experience for the practice, going beyond "counting minutes". In addition, this document also recommends the adoption of light-intensity PA during the day, emphasizing the importance that every movement counts.

The PA scenario becomes worrying when analyzing the data on their regular practice in Brazil, and that physical inactivity is one of the risk factors that may be responsible for the majority of deaths from $\mathrm{NCDs}^{15}$. According to data from Vigite ${ }^{16}$, in $2019,44.8 \%$ of Brazilian adults did not reach at least 150 minutes of moderate PA per week (leisure time, commuting, and occupational activity).

Thus, it is important to implement public policies aimed at reducing cardiovascular risk factors. The implementation of PA and physical exercise programs in Primary Health Care (PHC) is an action of fundamental importance for the promotion of the population's health ${ }^{17}$. In addition, PHC is an advantageous place for the promotion of $\mathrm{PA}^{18}$, especially when considering that Primary Health Care aims to offer universal access and program actions to prevent diseases.

However, although physical exercise programs are implemented in PHC, many studies evaluating the effects of these interventions do not consider participants who obtain a participation frequency of less than $75 \%$ or $80 \%$ in exercise sessions, or those who present consecutive absences in the analysis ${ }^{10,11,19,20}$. However, when it comes to the effect of the physical exercise program, these cutoff points may not reflect the effectiveness of the programs, given that a considerable portion of the participants do not reach this volume of exercise or participation. Thus, considering real-world problems, it's interesting to analyze the effects of interventions, because the participants excluded due to low participation may also have presented an improvement in some of the parameters studied.

Therefore, it is essential to investigate the volume of participation of all individuals who are included in these interventions, assuming that there is a difficulty in maintaining the adherence of the target audience ${ }^{21,22}$. The hypothesis of the present study is that even the individuals with a lower volume of participation in the exercise program may benefit from the physical exercise when compared to individuals with a greater volume of participation. Thus, the aim of the present study was to evaluate the effect of the volume of participation in exercise programs offered in PHC, for 24 weeks, on blood biochemical parameters of adult women.

\section{Methods}

The current study presents quantitative, quasi-experimental, and longitudinal characteristics. The survey was conducted in 3 Basic Health Units (BHU) in the city of Rio Claro, in the state of São Paulo, which in 2021 had an estimated population of 209,548 habitants and a Human Development Index of 0.803 in $2010^{23}$. The project was approved by the Research Ethics Committee of the Institute of Biosciences of Universidade Estadual Paulista (UNESP), campus Rio Claro, under opinion $\mathrm{n}^{\circ} 8594$.

Three BHUs that did not deliver any physical exercise intervention, with an adequate infrastructure (space for practice close to BHU and place to store the materials used in the sessions) were included.

After selection of the BHUs, the program dissemination began in places near the units, using pamphlets, banners, newspaper advertisements, and announcements by health professionals at the selected BHU.

In total, 140 registrations were made. The inclusion criteria for study were: age equal to or greater than 20 years, woman and not having limitations that could prevent the practice of physical exercise. Then, 82 women met the inclusion criteria and attended the first sessions of the interventions. Participants who were not included in the study remained in the programs. As exclusion criteria, we considered giving up the program before 24 weeks of intervention $(n=24)$ and individuals who did not attend any blood tests $(n=5)$.

Thus, the final sample of the present study consisted 
of 53 participants, who remained until the end of the intervention, regardless of their number of absences in the exercise sessions, divided into four different groups, according to the volume of participation.

Two interventions of physical exercise with different volumes were carried out: one intervention with a frequency of 3 weekly sessions and a duration of $90 \mathrm{~min}-$ utes each session and one with a frequency of 2 weekly sessions and a duration of 60 minutes each session.

Both interventions were characterized by the same class structure, use of materials, and exercise intensity, differing only in the frequency and duration of the sessions. The physical exercise sessions were divided into an initial part, main part, and final part. The initial part was reserved for the warm-up. In the main part, aerobic exercises (walking, dancing, gymnastics with music) and localized exercises (muscle strength and resistance) were offered, using materials such as gym mats, free weights (plastic bottles with water or sand), brooms, and shin guards. The final part was intended for relaxation (slow walking and final stretching). The initial and final part of the sessions were planned to include light intensity exercise (up to $3 \mathrm{MET}$ ) and the main part of light to moderate intensity exercise (up to $6 \mathrm{MET}$ ). Vigorous intensity exercises were not prescribed.

Both interventions were delivered by two researchers, graduated in physical education and with experience related to physical exercise programs at $\mathrm{PHC}$. There was no articulation with other health professionals of $\mathrm{PHC}$, in additional to helping publicize the programs.

The volume of participation of each individual was calculated by multiplying the number of classes frequented during the 24 weeks of intervention by the duration of the sessions (60 or 90 minutes).

After the calculation, the volumes were categorized into quartiles, $1^{\text {st }}$ quartile (540 to 2100 minutes) Low Volume Group (LVG, $\mathrm{n}=13$ ); $2^{\text {nd }}$ quartile (2160 to 2460 minutes) Low Medium Volume Group (LMVG, $\mathrm{n}=13) ; 3^{\text {rd }}$ quartile (3240 to 4320 minutes) High Medium Volume Group (HMVG, $\mathrm{n}=14$ ) and $4^{\text {th }}$ quartile (4410 to 5400 minutes) High Volume Group (HVG; $\mathrm{n}=13)$.

Blood biochemical analysis was performed to verify the levels of TC, HDL, LDL, TG, blood glucose, and CRP. The blood samples were collected $(10 \mathrm{ml})$ by a nurse of BHU, after the participant had fasted for 12 hours. In order to preserve the characteristics of the samples, after collection, they were stored in Styrofoam boxes with ice, sealed, and sent to the Biodynamics Laboratory at UNESP Rio Claro, where the analyses took place. In the laboratory, the collected blood was initially centrifuged and then the serum from this process was separated. After performing this step, the serum concentrations of TC, HDL, LDL, TG, blood glucose, and $\mathrm{CRP}$ were determined with commercial kits for measuring these variables, using the ELISA method (enzymatic immune assay).

The body mass index (BMI) was calculated according to the participants' body mass and height $\left(\mathrm{BMI}=\mathrm{Kg} / \mathrm{m}^{2}\right)$. Based on the calculation results, individuals with $B M I \geq 30 \mathrm{~kg} / \mathrm{m}^{2}$ were considered obese. Body mass was obtained using an anthropometric scale $\left(\right.$ Welmy $\left.{ }^{\circledR}\right)$ and for height a stadiometer was used. The waist-to-hip ratio (WHR) was obtained through waist and hip circumference measurements using a measuring tape $\left(\right.$ Sanny $\left.{ }^{\circledR}\right)$.

All collected information was recorded in the anamnesis of each participant (applied before the beginning of the intervention), which also included information such as age and self-reported diseases (hypertension and diabetes). In addition, the PA Readiness Questionnaire (PAR-Q) was applied before the beginning of the evaluations.

Blood pressure of all hypertensive participants was monitored once a week, using a digital device (Fuzzy LOGIC ${ }^{\circledR}$, BioLand model: 3001), and blood glucose of diabetic participants was measured once a month for insulin-dependent individuals and once every two months for non- insulin-dependent individuals, using a portable glucometer (Advantage ${ }^{\circledR}$, Eli Lilly do Brasil ltda.). These data are not presented as they were used only for monitoring purposes only.

For data presentation, descriptive analysis (mean and standard deviation) was used. To comparison of sample characteristics (continuous variables), one-way ANOVA was used and data normality was tested by the Kolmogorov Smirnov test. The statistical analysis of the blood biochemical parameters in relation to the time, group, and interaction (group $\mathrm{x}$ time) effect was performed using the Generalized Estimation Equation Model (GEE), adopting the gamma distribution (considering the quality of adjustment close to zero) and post-hoc comparisons by Bonferroni correction. All statistical analyses were performed using SPSS software, version 25.0, adopting a significance level of $5 \%$. The imputation of data was performed in 5 participants who did not undergo 1 blood test. 


\section{Results}

The final study sample consisted of 53 participants with a mean age of $56.58 \pm 10.15$ years. Information about the characterization of the sample, by groups, is detailed in Table 1.

The ANOVA showed a significant difference between groups for BMI ( $p=0.032)$, indicating that the BMI of the HMVG was different only from the LMVG (Bonferroni post-hoc, $p=0.042$ ). For age and WHR, no significant differences were found between the groups in the pre-intervention moment $(p>0.05)$.

Table 2 shows the results of the blood biochemical parameters of all groups in the pre- and post-intervention moments and the delta of the assessments. There was no interaction (group*time) for any of the studied variables $(\mathrm{p}>0.05)$.

Group effect was found for TC $(\mathrm{p}<0.001)$ and LDL ( $p=0.001)$. Regarding TC, the analysis showed a difference in HVG in relation to LVG ( $p<0.001)$, LMVG $(p<0.001)$ and HMVG $(p=0.003)$. The HVG

Table 1 - Characterization of the sample by group. Data expressed as mean and standard deviation for continuous variables and absolute frequency for categorical variables.

\begin{tabular}{|c|c|c|c|c|c|}
\hline Continuous variables & $\begin{array}{c}\text { LVG } \\
(\mathrm{n}=13)\end{array}$ & $\begin{array}{l}\text { LMVG } \\
(\mathrm{n}=13)\end{array}$ & $\begin{array}{l}\text { HMVG } \\
(\mathrm{n}=14)\end{array}$ & $\begin{array}{c}\text { HVG } \\
(\mathrm{n}=13)\end{array}$ & $\mathrm{p}$ - value \\
\hline Age (years) & $57.62 \pm 9.97$ & $56.31 \pm 12.18$ & $53.00 \pm 10.25$ & $59.69 \pm 7.66$ & 0.385 \\
\hline BMI $\left(\mathrm{kg} / \mathrm{m}^{2}\right)$ & $28.30 \pm 5.58$ & $27.61 \pm 6.72$ & $33.70 \pm 4.80^{\#}$ & $29.59 \pm 4.68$ & $0.032^{*}$ \\
\hline WHR & $1.09 \pm 0.07$ & $1.13 \pm 0.12$ & $1.06 \pm 0.99$ & $1.11 \pm 0.05$ & 0.221 \\
\hline Categorical variables & $\mathrm{n}$ & $\mathrm{n}$ & $\mathrm{n}$ & $\mathrm{n}$ & \\
\hline Obesity & 4 & 4 & 10 & 5 & - \\
\hline Hypertension & 4 & 4 & 5 & 6 & - \\
\hline Diabetes & 0 & 0 & 2 & 1 & - \\
\hline
\end{tabular}

Legend: * significant difference between groups; $\#$ = different from LMVG; LVG = low volume group; LMVG = low medium volume group; $\mathrm{HMVG}$ = high medium volume group; $\mathrm{HVG}$ = high volume group; BMI = body mass index; WHR = waist-to-hip ratio.

Note: Comparisons of continuous variables performed by one-way ANOVA.

Table 2 - Values pre- and post-physical exercise intervention, separated by group according to the volume of participation. Data expressed as mean and standard deviation.

\begin{tabular}{|c|c|c|c|c|c|}
\hline Variables & & $\operatorname{LVG}(\mathrm{n}=13)$ & LMVG $(\mathrm{n}=13)$ & HMVG $(\mathrm{n}=14)$ & $\operatorname{HVG}(\mathrm{n}=13)$ \\
\hline \multirow{3}{*}{$\mathrm{TC}(\mathrm{mg} / \mathrm{dl})$} & Pre & $163.60 \pm 22.29$ & $169.62 \pm 25.79$ & $170.06 \pm 40.29$ & $205.46 \pm 41.15$ \\
\hline & Post & $144.31 \pm 22.39^{* \#}$ & $143.85 \pm 21.92^{* \#}$ & $153.07 \pm 42.58^{* \#}$ & $214.54 \pm 43.53^{*}$ \\
\hline & $\Delta$ & -19.29 & -25.77 & -16.99 & +9.08 \\
\hline \multirow{3}{*}{$\begin{array}{l}\text { HDL } \\
(\mathrm{mg} / \mathrm{dl})\end{array}$} & Pre & $49.23 \pm 13.34$ & $52.31 \pm 15.55$ & $53.84 \pm 13.93$ & $57.77 \pm 12.42$ \\
\hline & Post & $52.54 \pm 9.37$ & $53.08 \pm 11.99$ & $54.29 \pm 11.53$ & $60.69 \pm 11.79$ \\
\hline & $\Delta$ & +3.31 & +0.77 & +0.44 & +2.92 \\
\hline \multirow{3}{*}{$\begin{array}{l}\mathrm{LDL} \\
(\mathrm{mg} / \mathrm{dl})\end{array}$} & Pre & $119.19 \pm 25.10$ & $129.46 \pm 29.05$ & $132.97 \pm 29.03$ & $146.85 \pm 40.86$ \\
\hline & Post & $97.08 \pm 14.49^{* \#}$ & $100.62 \pm 19.37^{* \#}$ & $106.71 \pm 30.01^{*}$ & $126.92 \pm 30.79^{*}$ \\
\hline & $\Delta$ & -22.12 & -28.85 & -26.26 & -19.92 \\
\hline \multirow{3}{*}{$\begin{array}{l}\text { TG } \\
(\mathrm{mg} / \mathrm{dl})\end{array}$} & Pre & $98.35 \pm 62.88$ & $110.15 \pm 58.98$ & $115.94 \pm 88.46$ & $127.31 \pm 62.58$ \\
\hline & Post & $115.15 \pm 61.82$ & $105.31 \pm 39.65$ & $128.36 \pm 63.22$ & $139.23 \pm 84.42$ \\
\hline & $\Delta$ & +16.81 & -4.85 & +12.42 & +11.92 \\
\hline \multirow{3}{*}{$\begin{array}{l}\text { BG } \\
(\mathrm{mg} / \mathrm{dl})\end{array}$} & Pre & $90.26 \pm 22.97$ & $86.77 \pm 9.25$ & $103.73 \pm 36.98$ & $97.62 \pm 14.32$ \\
\hline & Post & $90.15 \pm 14.61^{*}$ & $85.62 \pm 6.53^{*}$ & $98.36 \pm 24.84^{*}$ & $85.15 \pm 16.64^{*}$ \\
\hline & $\Delta$ & -0.11 & -1.15 & -5.37 & -12.46 \\
\hline \multirow{3}{*}{$\begin{array}{l}\text { CRP } \\
(\mathrm{mg} / 1)\end{array}$} & Pre & $3.88 \pm 2.30$ & $4.18 \pm 2.05$ & $3.84 \pm 1.66$ & $3.63 \pm 2.20$ \\
\hline & Post & $3.83 \pm 1.81$ & $3.54 \pm 1.22$ & $3.64 \pm 1.43$ & $2.76 \pm 1.43$ \\
\hline & $\Delta$ & -0.05 & -0.64 & -0.19 & -0.87 \\
\hline
\end{tabular}

Legend: * = significant difference between pre and post intervention moments; \# = significant difference from HVG; LVG = low volume group; $\mathrm{LMVG}=$ low medium volume group; $\mathrm{HMVG}=$ high medium volume group; $\mathrm{HVG}=$ high volume group; $\mathrm{CT}=$ total cholesterol; $\mathrm{HDL}=$ high density lipoprotein; $\mathrm{LDL}=$ low density lipoprotein; $\mathrm{TG}=$ triglycerides; $\mathrm{BG}=$ blood glucose; $\mathrm{CRP}=\mathrm{C}$-reactive protein; $\Delta=$ delta (post intervention - pre intervention). Note: Comparisons performed by the Generalized Estimation Equation Model. 
showing higher values pre and post intervention compared to all groups. For LDL, the difference was found for HVG in relation to LVG ( $\mathrm{p}=0.001)$ and LMVG ( $p=0.010)$, with HVG also showing higher values pre and post intervention compared to these groups. No statistical differences were found regarding the effect of the group for the variables HDL ( $\mathrm{p}=0.143), \mathrm{TG}(\mathrm{p}=$ $0.548)$, blood glucose ( $\mathrm{p}=0.157)$, and CRP ( $\mathrm{p}=0.486)$.

There was a positive effect time of the intervention for LDL $(p<0.001)$ and blood glucose $(p=0.016)$, presenting significant decrease in all analyzed groups. Regarding TC, there was also an effect of time ( $\mathrm{p}=$ 0.001), however, the effect was positive for the LVG, LMVG and HMVG (levels decreased significantly) and was negative for HVG (levels increased after the intervention). No statistical differences were found in the time effect for HDL $(p=0.372), T G(p=0.195)$, and CRP $(p=0.126)$.

\section{Discussion}

The aim of the present study was to evaluate the effect of the volume of participation in exercise programs offered in PHC, for 24 weeks, on blood biochemical parameters of adult women. The results obtained on the time effect can be considered as one of the most important elements of the study, given that significant differences were found for LDL, blood glucose, and TC.

Regarding LDL levels, all volume of participation groups in the exercise program presented a decrease in post-intervention with emphasis on LMVG $(\Delta=$ -28.85), which showed the greatest decrease in it. The literature demonstrates that although the effects of exercise are less evident for LDL levels, it is already known that exercise acts to increase circulation kinetics and prolongs the period in which LDL remains in the reduced form ${ }^{24}$, thus, these findings may be due to possible greater oxidation of fats caused by exercise ${ }^{25}$.

It is well established in the literature that exercise is important for blood glucose control and interventional studies focused on lifestyle change have shown significant alterations in fasting blood glucose ${ }^{13,26}$, thus, all groups in the current study presented decreased blood glucose after the intervention, with a focus on HVG $(\Delta=-12.46)$. In addition, it is noteworthy that the greatest decreases occurred in groups with higher volumes of participation (HMVG and HVG), which may be due to the presence of diabetic individuals in these groups, since diabetics are more sensitive to the insulin responses to exercise ${ }^{13}$.
The HVG was the only group that showed an increase in TC levels $(\Delta=+9.08)$, with a decrease in values in all other groups after the intervention, as shown in the literature ${ }^{24}$. TC levels are related to both PA and food intake and this may have been a determining factor for the increase in HVG levels, however, in this study, food intake was neither controlled nor evaluated. Other methodological limitation of the study is the absence of a control group, in addition to other factors that were not controlled, such as a possible practice of PA outside the program, psychological factors and medication use.

Considering the investigation of the effect of participating in an exercise program, the results of the group effect are also relevant, with significant differences in the variables TC, LDL, and blood glucose. The TC level of the group with the highest volume of participation (HVG) was different from the levels of all other groups, with higher pre- and post-intervention values. In LDL levels, the group with the highest participation volume (HVG), also showed higher levels in relation to the two groups with lower participation volumes (LVG and LMVG).

In line with our findings, previous studies such as the one by Lima et al. ${ }^{10}$, which compared cardiovascular risk in three groups assisted by the Family Health Strategy, through the practice of physical exercise with a volume of 3 sessions per week and duration of 60 minutes, found results similar to those of the present study, such as decreases in TC and LDL values, while the group considered physically inactive showed increases in these levels. However, it is noteworthy that the intervention was carried out over 12 months, while the intervention in the present study was carried out over 24 weeks. Another study, by Araújo et al. ${ }^{20}$, evaluated the effects of two physical exercise programs, with 4 weekly sessions and a duration of 60 minutes, over 16 weeks, on health parameters (among them, the biochemical profile) of women attended at a $\mathrm{BHU}$, and obtained similar results to the present study, such as a decrease in blood glucose and $\mathrm{TC}$ values in both groups that practiced exercise. It is noteworthy that the aforementioned studies considered participation in less than $75 \%{ }^{10}$ and $80 \%{ }^{20}$ of the program as an exclusion criterion.

The results did not indicate changes in the TG, HDL, and CRP variables. The literature shows that the TG concentration can change due to the consumption of carbohydrates and fats ${ }^{24}$, however, variables related to eating habits were not measured in this study. The 
literature also indicates that exercise can provide a subtle increase in HDL levels ${ }^{24}$, however, studies on this topic are still conflicting ${ }^{27,28}$.

CRP levels may not have changed due to the insufficient time of intervention, since physical exercise interventions performed in PHC lasting 12 months showed a decrease in CRP levels ${ }^{11}$, however, it is noteworthy that the authors used a cut-off point for the participation of individuals. In addition, in a meta-analysis ${ }^{29}$ carried out with strength, aerobic, and combined training, it was found that the practice of physical exercise is related to a decrease in CRP levels, however, greater improvements occurred in association with a decrease in BMI.

Importantly, to our knowledge, no studies were found in the literature that aimed to investigate the volume of participation in exercise interventions in PHC. Instead, most interventional studies carried out in PHC do not consider in the analysis participants who do not reach a minimum of 75 to $80 \%$ of participation the intervention or who have consecutive absences without prior justification ${ }^{10,11,19,20}$. Thus, the main finding of our study is that, regardless of the individual's volume of participation in physical exercise interventions in PHC, the benefits of the practice can be remarkable, considering the blood biochemical parameters. This information again remembers to the important message of the WHO guideline $\mathrm{W}^{14}$, as the finding of the present study was in line with the practice of PA regardless of the quantity, reinforcing the theme "Every move counts", mainly aiming at the quality of the experiences.

The evidence found in this study can directly collaborate in the actions of the PHC, mainly for public policies, contributing to the implementation of more PA interventions and reinforcing the importance of adherence in programs regardless of the participation rate. This fact is mainly confirmed by the characteristics of the Unified Health System (SUS), such as the guarantee of universal and free access to health actions, thus, awareness actions for the population, within the context of the SUS, could be effective for the propagation of the importance and practice of PA in PHC, in addition to participation in other health actions. Considering that one of the PHC main objectives is to offer health promotion and disease prevention actions, the delivery of physical exercise and PA programs, health counseling, support groups, among other actions are essential.
As limitations of the present study, we can indicate the absence of a control group in order to allow better comparisons regarding the effect of the intervention, the absence of application of a dietary recall, which would enable analysis of the results of biochemical variables in conjunction with diet and physical exercise. The strengths include the method used to collect the variables (blood biochemical parameters) which is considered a direct method, the duration of the intervention that is longer than other studies in the literature $^{8,20,30}$, the permanence of 53 participants until the end of the intervention, considered an adequate sample, and the originality of the study, since no other studies were found that assess low participation of individuals in exercise programs in PHC.

The results of this study could contribute to the implementation of public policies focused on health, mainly aimed at the practice of physical exercise, which is directly associated with a lower risk for cardiovascular diseases $^{5}$. In addition, the implementation of programs in $\mathrm{PHC}$ was shown to be a viable alternative, as it is an advantageous place for the practice of physical activity ${ }^{18}$. In the case of studies carried out in PHC, the difficulty in maintaining adherence of the target audience is considered and, in order to encourage greater participation in the programs, the non-exclusion of participants due to the volume of participation may be a feasible and effective attempt to increase adherence to exercise programs. Furthermore, it is suggested that future research consider the possibility of analyzing the data considering the low volume of participation of individuals.

Thus, it is concluded that the physical exercise program offered in PHC for 24 weeks contributed to a significant reduction in LDL and blood glucose levels and maintenance of HDL, TG, and CRP levels, regardless of the volume of participation of individuals in the program. For TC, there was a significant decrease in the groups with smaller volumes and an increase in the group with higher volume. Thus, the development of exercise programs in PHC seems to be a viable solution for health promotion and disease prevention for all intervention participants, even those with lower attendance. It is suggested that randomized controlled studies be performed to provide better evidence on the proposed theme.

\section{Conflict of interest}

The authors declare no conflict of interest. 


\section{Funding}

The present work was conducted with support from the Coordenação de Aperfeiçoamento de Pessoal de Nível Superior - Brasil (CAPES, Institutional Doctoral Scholarship) and the Fundação de Amparo à Pesquisa do Estado de São Paulo - Brasil (FAPESP, Process 2011/15862-2).

\section{Author's contributions}

Brunheroti KA, participated in the design and writing of the manuscript, analysis and interpretation of data. Andaki ACR carried out the critical review of the intellectual content. Kokubun E participated in the initial conception of the study and in the critical review of the intellectual content. Papini CB participated in the design of the manuscript, analysis and interpretation of data and critical review of the content.

\section{Acknowledgments}

The authors are grateful to the Municipal Health Foundation of Rio Claro, São Paulo and the Physical Activity, Sport and Health Center (NAFES) of the São Paulo State University Júlio de Mesquita Filho.

\section{References}

1. Malta DC, Silva AG, Cardoso LSM, Andrade FMD, Sá ACMGN, Prates EJ, et al. Doenças Crôni-cas Não Transmissíveis na Revista Ciência \& Saúde Coletiva: um estudo bibliométrico. Ciênc. saúde coletiva. 2020;25(12):4757-69.

2. Brasil. Ministério da Saúde. Secretaria de Atenção à Saúde. Departamento de Atenção Básica. Di-retrizes para o cuidado das pessoas com doenças crônicas nas redes de atenção à saúde e nas li-nhas de cuidado prioritárias. Brasília: Ministério da Saúde. 2013. Available in: <https://bvsms.saude.gov.br/bvs/ publicacoes/diretrizes\%20_cuidado_pessoas\%20_doencas_ cronicas.pdf $>$. [2021 May].

3. Melo SPSC, Cesse EAP, Lira PIC, Rissin A, Cruz RSBLC, Filho MB. Doenças crônicas não transmissíveis e fatores associados em adultos numa área urbana de pobreza do nordeste brasi-leiro. Ciênc. saúde coletiva. 2019;24(8):3159-68.

4. Organização Pan-Americana de Saúde / OPAS. Doenças cardiovasculares. OPAS, 2017. Available in: <https://www. paho.org/bra/index.php?option=com_content\&view=article \&id=5253:doencas-cardiovasculares\&Itemid=1096> . [2021 December].

5. Nystoriak MA, Bhatnagar A. Cardiovascular effects and benefits of exercise. Front. Cardiovasc. Med. 2018;135(8):01-11.

6. Neto FR, Lopes GH. Body composition modifications in people with chronic spinal cord injury after supervised physical activity. J. Spinal Cord Med. 2011;34(6):586-93.

7. Meurer ST, Lopes ACS, Almeida FA, Mendonça RD, Benedetti TRB. Effectiveness of the VAMOS Strategy for Increasing Physical Activity and Healthy Dietary Habits: A Randomized Controlled Community Trial. Health Educ. Behav. 2019;46(3):406-16.

8. Vianna MVA, Cáder SA, Gomes ALM, Guimarães AC, Seixas-da-Silva IA, Rêgo ARON, et al. Aerobic conditioning, blood pressure (BP) and body mass index (BMI) of older participants of the Brazilian Family Health Program (FHP) after 16 weeks of guided physical activity. Arch. Ge-rontol. Geriatr. 2012;54:210-13.
9. Ogalha C, Luz E, Sampaio E, Souza R, Zarife A, Neto $\mathrm{MG}$, et al. A randomized, clinical trial to evaluate the impact of regular physical activity on the quality of life, body morphology and met-abolic parameters of patients with AIDS in Salvador, Brazil. J Acquir. Immune Defic. Syndr. 2011;57(3):179-185.

10. Lima AM, Werneck AO, Cyrino E, Farinatti P. Supervised training in primary care units but not self-directed physical activity lowered cardiovascular risk in Brazilian lowincome patients: a controlled trial. BMC Public Health. 2019;19:1738.

11. Papini CB, Nakamura PM, Zorzetto LP, Thompson JL, Phillips AC, Kokubun E. The effect of a community-based, primary health care exercise program on inflammatory biomarkers and hor-mone levels. HPC; Mediators Inflamm. 2014; $14: 1-7$.

12. Costa RR, Butelli ACK, Vieira AF, Coconcelli L, Magalhães RL, Delevatti RS, et al. Effect of Strength training on lipid and inflammatory outcomes: systematic review with meta-analysis and meta-regression. J. Phys. Act. Health. 2019;16(6):477-91.

13. Zhou ZZ, Sun B, Huang S, Zhu C, Bian M. Glycemic variability: adverse clinical outcomes and how to improve it? Cardiovasc Diabetol. 2020;19:102.

14. World Health Organization / WHO. WHO guidelines on physical activity and sedentary behavior. Geneva: World Health Organization. 2020.

15. World Health Organization / WHO. Global status report on noncommunicable diseases 2014. Geneva: WHO. 2014. Available in: < https://apps.who.int/iris/ handle/10665/148114>. [2020 June].

16. Brasil. Ministério da Saúde. Secretaria de Vigilância em Saúde. Departamento de Análise em Saú-de e Vigilância de Doenças Não Transmissíveis. Vigitel Brasil 2019: vigilância de fatores de risco e proteção para doenças crônicas por inquérito telefônico. Brasília, Ministério da Saúde. 2020. Available in: < https://bvsms.saude.gov.br/bvs/publicacoes/ vigitel_brasil_2019_vigilancia_fatores_risco.pdf $>$ [2020 March].

17. Silva CRM, Bezerra J, Soares FC, Mota J, Barros MVG, Tassiano RM. Percepção de barreiras e facilitadores dos usuários para participação em programas de promoção da atividade física. Cad. Saude Publica. 2020;36(4):e00081019.

18. Brasil. Ministério da Saúde. Plano de Ações Estratégicas para o Enfrentamento das Doenças Crônicas não transmissíveis (DCNT) no Brasil2011-2022.Brasília,Brasil.2011.Available in: < https://portaldeboaspraticas.iff.fiocruz.br/biblioteca/ plano-de-acoes-estrategicas-para-o-enfrentamento-dasdoencas-cronicas/>. [2021 June].

19. Saida TGRH, Sorensen TJ, Lanberg H. Long-term exercise adherence after public health training in at-risk adults. Ann. Phys. Rehabil. Med. 2017;60(4):237-43.

20. 20 - Araújo SP, Oliveira NC, Corrêa CF, Pontes HT, Cerqueira PA, Portes LA. Mulheres na atenção primária à saúde: exercício físico, estilo de vida e fatores de risco cardiovascular. Rev Eletron Comun Inf Inov Saúde. 2017;11(3):1-13.

21. Monteiro GR, Silva RJS. The length of stay in community physical activity program does not ex-ceed two years. Rev Bras Cineantropom Desempenho Hum. 2014;16(6):608-17.

22. Lovato NS, Loch MR, González AD, Lopes MLS. Assiduidade a programas de atividade física oferecidas por Unidades Básicas de Saúde: o discurso de participantes muito e pouco assíduos. Rev Bras Ativ Fís Saúde. 2015;20(2):184-192. 
23. IBGE. Contagem populacional.IBGE Cidades. Disponível em: $<$ https://cidades.ibge.gov.br/brasil/sp/rio-claro/panorama>. [2021 September].

24. Faludi AA, Izar COM, Saraiva JFK, Chacra APM, Bianco HT, Afiune N, et al. Atualização da Diretriz Brasileira de Dislipidemias e Prevenção da Aterosclerose. Arq Bras Cardiol. 2017;109(2Supl.1):1-76.

25. Maunder ED, Plews DJ, Kilding A. Contextualizing Maximal Fat Oxidation During Exercise: De-terminants and Normative Values. Front. Physiol. 2018;23(9):599.

26. Rankin P, Morton DP, Diehl H, Gobble J, Morey P, Chang E. Effectiveness of a volunteer- deliv-ered lifestyle modification program for reducing cardiovascular disease risk factors. Am J Cardi-ol. 2012;109(1):82-6.

27. Fraga AS, Ladeia AMT, Sá CKC, Tenório MCC. Efeito do exercício sobre os níveis de HDL-C: uma revisão sistemática de metanálises. Rev Bras Med Esporte. 2017;23(6): 488-494.
28. Ruiz-Ramie JJ, Barber JL, Sarzynski MA. Effects of exercise on HDL functionality. Curr. Opin. Lipidol. 2019;30(1):16-23.

29. Fedewa MV, Hathaway ED, Ward-Ritacco CL. Effect of exercise training on $\mathrm{C}$-reactive protein: a systematic review and meta-analysis of randomized and non-randomized controlled trials. Br. J. Sports Med. 2016;51(8):670-76.

30. Benedetti TRB, Rech CR, Konrad LM, Almeida FA, Brito FA, Chodzko-Zajko W, et al. Re-thinking physical activity programs for older brazilians and the role of public health centers: a randomized controlled trial using the RE-AIM Model. Public Health Front. 2020; 8: 1-11.

Received: 30/09/2021

Approved: 25/12/2021

\section{Quote this article as:}

